\title{
Soil organic carbon and iron oxides affects soil aggregate stability under straw returning and potassium fertilizer in a rice-rape cropping system
}

\author{
Bin Xue ${ }^{1}$, Li Huang ${ }^{2}$, Jianwei $\mathrm{Lu}^{3}$, Xiaokun $\mathrm{Li}^{2}$, Ruili $\mathrm{Gao}^{1}$, and Kamran Muhammad ${ }^{2}$ \\ ${ }^{1}$ Ningxia University \\ ${ }^{2}$ Huazhong Agricultural University \\ ${ }^{3}$ Huazhong Agriculture University
}

January 8, 2022

\begin{abstract}
Soil organic carbon (SOC) and iron (Fe) oxides are known to affect the formation and stability of soil aggregates. However, the effects of SOC and Fe oxides on soil aggregates stability under straw returning and potassium (K) fertilizer application in paddy-upland rotation systems are less well-studied. This study primarily investigated soil aggregates dynamics and their stability indices (mean weight diameter, MWD; geometric mean diameter, GMD), and soil binders (SOC and iron oxides) after rice and rape harvests under four treatments: F1, mineral nitrogen $(\mathrm{N})$ and phosphorus $(\mathrm{P})$ fertilizer; F2, mineral NPK fertilizer; F3, mineral NP fertilizer with straw returning; F4, mineral NPK fertilizer with straw returning in rice-rape cropping system. Straw returning treatments (F3 and F4) significantly ( $\mathrm{P}<0.05)$ increased MWD and GMD, but the effect of K is not obvious. The soil aggregates stability was higher after the rape harvest than rice harvest, but SOC content was the opposite. Straw input can increase the contents of SOC, alkane-C and aromatic-C concentrations, especially in $>0.25$ mm aggregates. Long-term straw incorporation significantly increased the amorphous (Feo) and complex iron oxides (Fep) concentrations. SOC and Fep in bulk soil and $>5 \mathrm{~mm}$ aggregates were significantly related with MWD, and significant relationship was observed between MWD and Feo in $<5 \mathrm{~mm}$ fractions. Thus, the high levels of SOC, alkane-C, Feo and Fep in soil after straw returning were responsible for the aggregate stability, but the effect of potassium application is not obvious in a rice-rape cropping system.
\end{abstract}

- Straw returning significantly improved soil aggregation and stability.

- The effect of $\mathrm{K}$ fertilizer on the stability of aggregates and binder is not obvious.

- Seasonal variability affected soil aggregate stability and SOC contents.

- SOC and Fep in $>5 \mathrm{~mm}$ fractions improved the stability of aggregates, while Feo in $<5 \mathrm{~mm}$ fractions.

Hosted file

Main maunscript.docx available at https://authorea.com/users/454536/articles/552136-soilorganic-carbon-and-iron-oxides-affects-soil-aggregate-stability-under-straw-returningand-potassium-fertilizer-in-a-rice-rape-cropping-system

\section{Hosted file}

Figure legends.docx available at https://authorea.com/users/454536/articles/552136-soilorganic-carbon-and-iron-oxides-affects-soil-aggregate-stability-under-straw-returningand-potassium-fertilizer-in-a-rice-rape-cropping-system

\section{Hosted file}


Figures.docx available at https://authorea.com/users/454536/articles/552136-soil-organiccarbon-and-iron-oxides-affects-soil-aggregate-stability-under-straw-returning-andpotassium-fertilizer-in-a-rice-rape-cropping-system

\section{Hosted file}

Tables.docx available at https://authorea.com/users/454536/articles/552136-soil-organiccarbon-and-iron-oxides-affects-soil-aggregate-stability-under-straw-returning-andpotassium-fertilizer-in-a-rice-rape-cropping-system 